\title{
Ультразвукові та цитологічні характеристики радіойодчутливості метастазів папілярного раку щитоподібної залози
}

\section{Г.В. Зелінська,} Є.А. Шелковий

ДУ «Інститут ендокринології та обміну речовин ім. В.П. Комісаренка НАМН України»

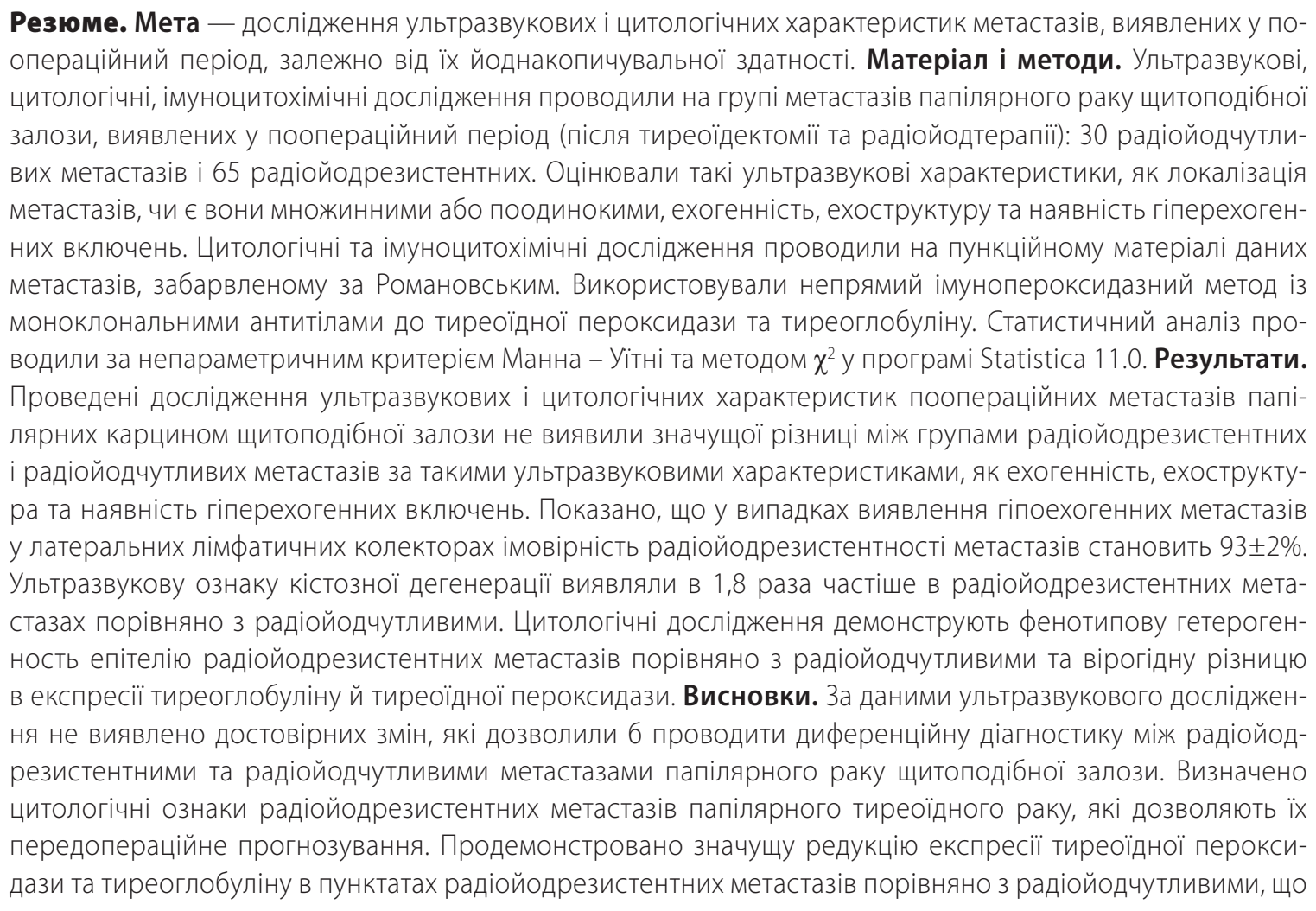

* Адреса для листування (Correspondence): ДУ «Інститут ендокринології та обміну

речовин ім. В.П. Комісаренка НАМН України», вул. Вишгородська, 69, м. Київ, 04114,

Україна. E-mail:zdovado@ukr.net

(с) Г.В. Зелінська, Є.А. Шелковий 
Оригінальні дослідження

є підставою передопераційного прогнозування радіойодрезистентності поопераційних метастазів папілярного тиреоїдного раку. Виявлені за даними ультразвукової діагностики метастатичні лимфатичні вузли шиї дозволяють проводити подальші імуноцитохімічні та цитологічні дослідження, що може підвищити ефективність діагностики метастазів високодиференційованого раку щитоподібної залози й полегшити вибір подальшого лікування.

Ключові слова: папілярна карцинома щитоподібної залози, ультразвукове дослідження, тонкоголкова аспіраційна пункційна біопсія, радойодрезистентні метастази.

Наразі доведено, що прямим медичним наслідком Чорнобильської катастрофи стало різке зростання захворюваності на рак щитоподібної залози (ЩЗ), надто серед людей віком до 18 років $[1,2]$. Через 4 роки після Чорнобильської катастрофи частота захворювань на рак ЩЗ у дітей збільшилась у 4,8 раза, а наступними роками перевищила передаварійні показники в 10 разів [3, 4]. Але, на відміну від карцином інших локалізацій, диференційований рак ЩЗ у більшості випадків має сприятливий прогноз - летальні випадки фіксують досить зрідка (в 4-6\% випадків), 5-річне виживання хворих становить близько 98\%, а 20-30-річне - перевищуе 90\% [5-7]. Дуже високими є й показники безрецидивного 10-20-30-річного виживання - понад 70\%, 60\% i 50\% відповідно [8, 9]. Ключовим моментом успішного лікування диференційованого раку ЩЗ і його метастазів є використання радіойодтерапії - специфічного високоефективного таргентного методу. Радіойодтерапія грунтується на унікальній здатності клітин ЩЗ акумулювати радіойод і використовувати його в синтезі тиреоїдних гормонів. Але, на жаль, навіть на тлі стандартної високоефективної терапії (тиреоїдектомія, радіойодтерапія та супресивна терапія) в поопераційний період з'являються метастази папілярного тиреоїдного раку, серед яких є як радіойодчутливі (РЙЧМ), клітини яких накопичують радіойод, так і радіойодрезистентні (РЙРМ), клітини яких втрачають здатність до накопичення ізотопу. РЙРМ виявляють у 4-20\% випадків, і для них радіойодтерапія не є ефективною [10]. За даними різних авторів, втрачання тиреоїдними раками здатності до накопичення радіойоду корелює зі зниженням медіани виживання до 2,5-3,5 року [11, 12]. Безумовно, актуальними є клініко-біологічні дослідження РЙРМ із метою виявлення їх особливостей, які б дозволили здійснювати їх раннє прогнозування та діагностику.

Ультразвукове дослідження (УЗД) і тонкоголкова аспіраційна пункційна біопсія (ТАПБ) із наступним цитологічним дослідженням пунктатів є основними методами передопераційної діагностики новоутворень ЩЗ. УЗД є чутливішим методом виявлення патологічних лімфатичних вузлів (ЛВ) порівняно з клінічними методами дослідження, чутливість методу становить відповідно 96,8\% і 73,3\% [13]. Також УЗД є точнішим у виявленні метастатичних ЛВ шиї порівняно за позитрон-емісійну та комп'ютерну томографію [14]. Хоча УЗД є досить ефективним у визначенні метастазів ЛВ шиї, чітко виявити можливо лише ЛВ діаметром понад 2 мм, також існують обмеження для виявлення віддалених метастазів за допомогою УЗД [15]. За допомогою УЗД фахівець може чітко оцінити морфологію ЛВ та васкуляризацію шляхом кольорового дуплексного картування. Проведення УЗД за сірою шкалою дозволяє виявити особливості, які допомагають запідозрити метастатичне ураження або наявність лімфопроліферативного захворювання. Ехографічна оцінка ЛВ надає відомості про їх розмір, форму та внутрішню ехоструктуру [16]. Використання доплерографії допомагає оцінити судинний малюнок ЛВ і виявити патологічні зміни [17]. Проведення тонкоголкової аспіраційної пункційної біопсії (ТАПБ) підозрілих на метастази ЛВ дозволяє виробити терапевтичну тактику подальшого лікування [18].

У літературні описано результати гістологічних і молекулярно-генетичних досліджень РЙРМ, але не висвітлено питання кореляції ультразвукових і цитологічних ознак із радіойодчутливістю метастазів папілярного тиреоїдного раку [19-21]. Тому метою даної роботи була комплексна оцінка ультразвукових і цитологіч- 
них характеристик метастазів, виявлених у поопераційний період, залежно від їх йоднакопичувальної здатності.

\section{Матеріал і методи}

У роботі використано матеріал, отриманий від 95 пацієнтів чоловічої та жіночої статі віком від 10 до 67 років, які проходили обстеження, хірургічне лікування та радіойодтерапію в клініці ДУ «ннститут ендокринології та обміну речовин ім. В.П. Комісаренка НАМН України». До групи обстежених включено хворих із верифікованим діагнозом папілярної карциноми (ПК) ЩЗ, яким проводили тиреоїдектомію з дисекцією ЛВ шиї. Усім хворим виконано екстрафасціальну тиреоїдектомію та центральну дисекцію - видалення передгортанних, перед- і паратрахеальних ЛВ із жировою тканиною. У випадках виявлення метастазів у бічних колекторах додатково проводили одноабо двобічну селективну дисекцію шиї - футлярне видалення лімфовузлів із навколишньою жировою тканиною вздовж судинно-нервового пучка шиї зі збереженням груднино-ключице-сосцеподібного м'яза, внутрішньої яремної вени та додаткового нерва. Після планової радіойодтерапії та контрольних УЗД виникала підозра на наявність метастатичного ураження ЛВ шиї у хворих. Усім хворим проведено ТАПБ ЛВ із наступним цитологічним дослідженням та підтверджено наявність метастазів папілярного тиреоїдного раку в ЛВ шиї. Після обстежень хворих розподілили на групи з РЙЧМ і РЙРМ. Ультразвукові та цитологічні дослідження проводили в групі хворих із РЙЧМ, яка включала 30 осіб: 24 (80,0\%) жінок і $6(20,0 \%)$ чоловіків (середній вік $-31,53 \pm 10,2$ р.). Групу хворих із РЙРМ становили 65 пацієнтів: 49 (75,4\%) жінок і 16 (24,6\%) чоловіків (середній вік $-44,61 \pm 15,8$ р.).

Цитологічні та імуноцитохімічні дослідження проводили на матеріалі ТАПБ ЛВ. Цитологічні дослідження проводили на пунктатах, фіксованих метанолом і забарвлених за методом Романовського, імуноцитохімічні на препаратах, забарвлених за Романовським методом відновлення активності антигенних детермінант [22]. Застосовували непрямий імунопероксидазний метод із використанням моноклональних антитіл миші проти тиреоїдної пероксидази (ТPO-47, DakoCytomation, Данія, розведення 1:50) і тиреоглобуліну (DAK-Tg6,
Dako, Данія, 1:100). Як вторинні використовували антитіла проти $\gamma$-глобулінів миші, мічені пероксидазою хрону (DakoCytomation, Данія). Після імуноцитохімічної реакції ядра клітин забарвлювали розчином гематоксиліну. Для визначення відсотка імунопозитивних клітин підраховували щонайменше 1000 тиреоцитів у кожному випадку. Статистичне опрацювання даних виконували за непараметричним методом Манна - Уїтні та методом $\chi^{2}$. Розрахунки виконано в програмі Statistica 11.0.

\section{Результати та обговорення}

За результатами ретроспективного аналізу УЗД поопераційних метастазів встановлено, що РЙЧМ мали 9 (30,0\%) хворих у центральному лімфатичному колекторі (передгортанні, пре- та паратрахеальні ЛВ), 11 (36,7\%) - у латеральних колекторах окремо, 10 (33.3\%) - у латеральних і центральних. РЙРМ виявлено у 23 (35,4\%) хворих у центральному лімфатичному колектоpi, у 14 (21,5\%) - у латеральних лімфатичних колекторах окремо та у $28(43,1 \%)$ - у латеральних і центральних. У 9 (30,0\%) хворих із РЙЧМ виявлено поодинокі метастази, у 21 (70,0\%) множинні. У групі РЙРМ поодинокі метастази виявлено у 21 (32,3\%) хворого, множинні в $44(67,7 \%)$. Не виявлено значущої різниці за методом $\chi^{2}$ у частоті поодиноких і множинних метастазів залежності від радіойодчутливості поопераційних метастазів ПК ЩЗ. За даними УЗД, РЙЧМ у 43,3\% випадків мали знижену ехогенність, гіперехогенні ЛВ виявлено в 56,7\% спостережень. РЙРМ мали знижену ехогенність у 55,4\% випадків, гіперехогенні метастази виявлено в 44,6\% спостережень. Кістозні зміни виявлено у $23,3 \%$ хворих із РЙЧМ та $43,07 \%$ із РЙРМ. Наявність гіперехогенних включень виявлено в 66,7\% РЙЧМ та 72\% РЙРМ ПК Щ3. Причому не знайдено вірогідної різниці в частоті таких УЗ-ознак тканин метастазів, як гіперабо гіпоехогенність, наявність кістозних змін і гіперехогенних включень, між РЙРМ і РЙЧМ ПК ЩЗ (рис. 1-3). Хоча статистично різницю в частоті УЗ-ознаки кістозної дегенерації не підтверджено, кістозні зміни виявляли майже вдвічі частіше в групі РЙРМ порівняно з РЙЧМ.

За даними комплексного аналізу локалізації метастазів та ехогенності встановлено гіперехогенні метастази латеральних лімфатичних 


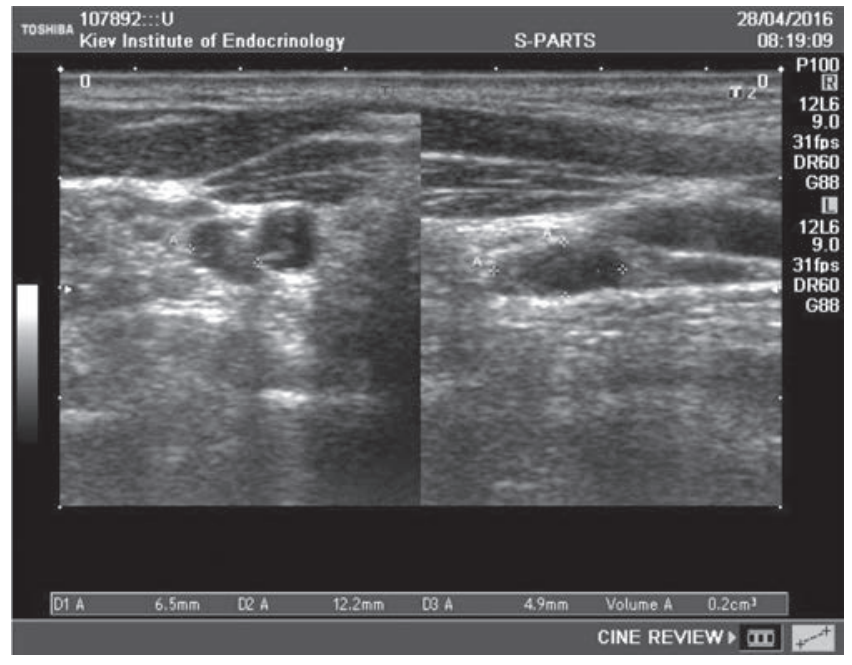

Рис. 1. Ультразвукові зображення РЙРМ. Гіпоехогенна ехоструктура, наявність кістозної дегенерації.

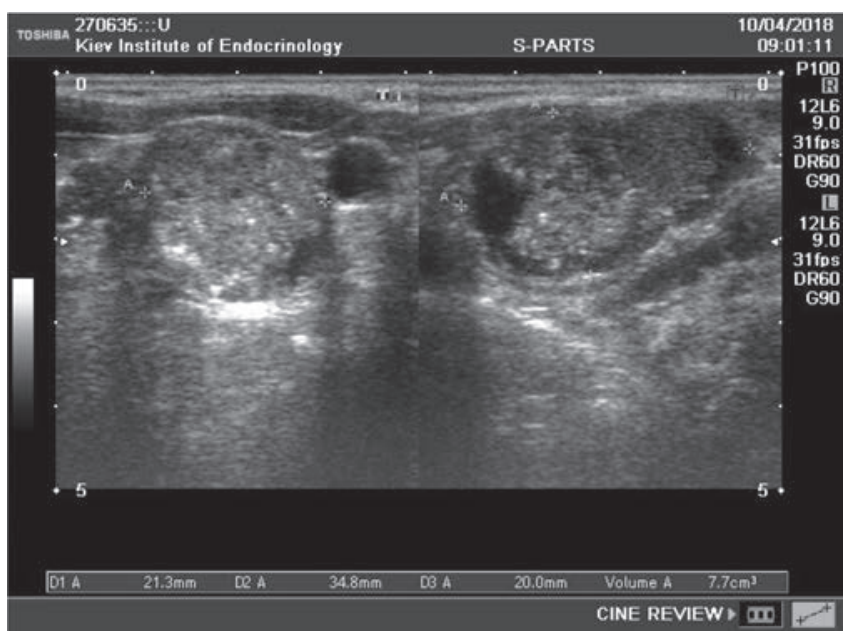

Рис. 2. Ультразвукові зображення РЙРМ. Гіперехогенна ехоструктура, наявність кістозної дегенерації та гіперехогенних включень.

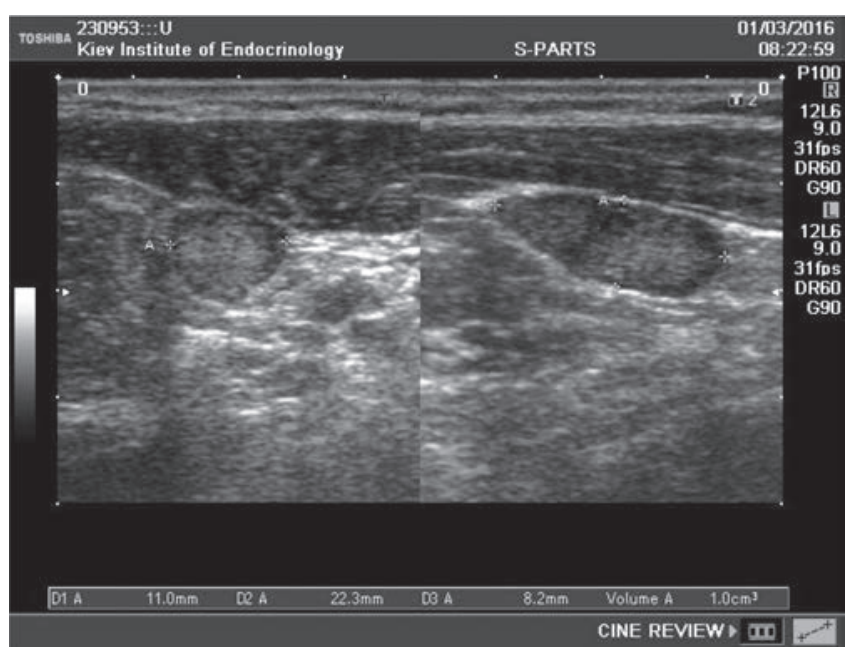

Рис. 3. Ультразвукові зображення РЙЧМ. Гіперехогенна гомогенна ехоструктура. колекторів у $91 \pm 3 \%$ випадків серед хворих із РЙЧМ, тоді як гіперехогенні РЙРМ - у 50\% хворих. Гіпоехогенні метастази центрального лімфатичного колектора виявлено в $77 \pm 6 \%$ випадків серед хворих із РЙЧМ і в $76 \pm 3 \%$ - iз РЙРМ. Досить важливою знахідкою є те, що у випадках виявлення гіпоехогенних метастазів у латеральних лімфатичних колекторах імовірність РЙРМ становила $93 \pm 2 \%$.

Ехографічні характеристики виявлених за допомогою УЗД метастатичних ЛВ (РЙРМ і РЙЧМ) наведено в таблиці 1.

Цитологічні та імуноцитохімічні дослідження проводили на матеріалі ТАПБ тих самих поопераційних метастазів, які досліджували за допомогою УЗД. Продемонстровано фенотипову гетерогенність епітелію РЙРМ порівняно з РЙЧМ. Це проявлялось у наявності особливої субпопуляції тиреоцитів, які виявляли в пунктатах 26\% РЙРМ і відсутності їх у РЙЧМ, і ці клітини відрізнялись від загальної популяції епітелію за цитологічними та імуноцитохімічними характеристиками. Клітини цієї субпопуляції мали світліший порівняно з іншими тиреоцитами вигляд та чітку межу, не містили тиреоглобуліну та епітеліальних глікопротеїнів ерСАМ (рис. 4). У пунктатах 24\% РЙРМ виявлено особливі комплекси псамомних тілець і вакуолізованих клітин, які були відсутніми в РЙЧМ (рис. 5). Цитопатологи світу описують множинні псамомні тільця, розташовані всередині фрагментів тканин у матеріалі ТАПБ дифузно-склерозуючого варіанта ПК Щ3 [23]. Цей варіант, за даними ВООЗ, вважається одним із найагресивніших варіантів ПК Щ3 [24, 25]. Ми спостерігали подібні комплекси в матеріалі РЙРМ та їх відсутність у пунктатах РЙЧМ, що може розцінюватися як цитологічна ознака агресії та радіойодрезистентності ПК ЩЗ. Крім того, ознаки кістозної дегенерації виявлено в 37\% РЙРМ і лише в 1,5\% РЙЧМ. Визначено вірогідну різни-

Таблиця 1. Частота ехографічних характеристик РЙРМ і РЙЧМ папілярної карциноми Щ3, \% (n)

\begin{tabular}{llll}
\hline Уз-характеристики & $\begin{array}{l}\text { РЙРМ } \\
(\mathbf{n}=65)\end{array}$ & $\begin{array}{l}\text { РЙчM } \\
(\mathbf{n}=30)\end{array}$ & $\mathbf{p}$ \\
\hline Гіпоехогенність & $55,4(36)$ & $43,3(13)$ & $\mathrm{p}=0,2746$ \\
Гіперехогенність & $44,6(29)$ & $56,7(17)$ & $\mathrm{p}=0,2746$ \\
Солідна ехоструктура & $66,93(37)$ & $76,7(23)$ & $\mathrm{p}=0,0637$ \\
Кістозні зміни & $43,07(28)$ & $23,3(7)$ & $\mathrm{p}=0,0637$ \\
Гіперехогенні включення & $72(47)$ & $66,7(20)$ & $\mathrm{p}=0,5751$ \\
\hline
\end{tabular}




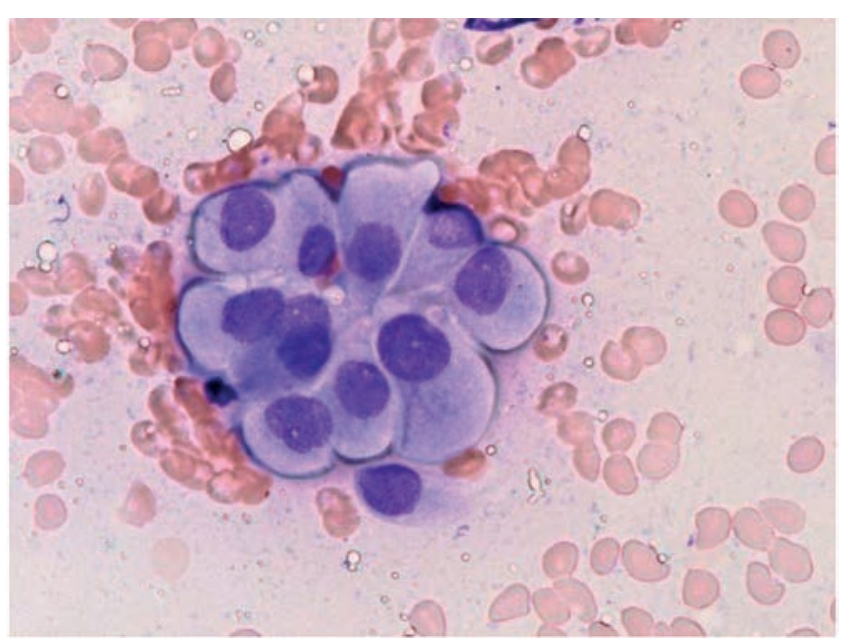

Рис. 4. Особлива субпопуляція тиреоцитів у пунктаті РЙРМ. Забарвлення за Романовським, х400.

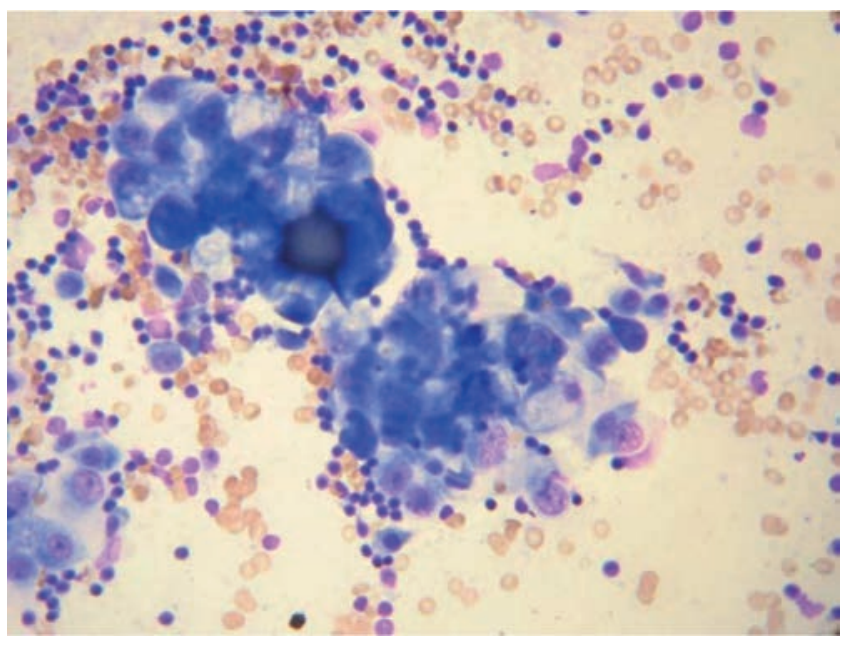

Рис. 5. Комплекс псамомних тілець і вакуолізованих клітин у пунктаті РЙРМ ПК ЩЗ. Забарвлення за Романовським, ×400.

цю між частотою описаних цитологічних ознак у групах РЙРМ і РЙРМ ПК ЩЗ. Водночас не виявлено значущої різниці в частоті оксифільноклітинних змін між групами РЙРМ і РЙЧМ.

Імуноцитохімічні дослідження експресії тиреоїдної пероксидази та тиреоглобуліну й аналіз експресії антигенів показали значущу різницю за цими показниками між досліджуваними групами РЙРМ і РЙЧМ ПК ЩЗ (табл. 2).

Отже, проведене дослідження ультразвукових характеристик поопераційних метастазів ПК ЩЗ не виявило значущої різниці між групами РЙРМ і РЙЧМ за такими показниками, як ехогенність, ехоструктура та наявність гіперехогенних включень. Настороженість щодо радіойодрезистентності метастазів, як виявилось, має викликати їх локалізація в латеральному колекторі шиї в поєднанні з ознакою гіпоехоген- таблиця 2. Частота цитологічних ознак і медіани відсотка ТПО- та ТГ-позитивних клітин у пунктатах РЙРМ і РЙЧМ папілярної карциноми щитоподібної залози, \% (n)

\begin{tabular}{|c|c|c|c|}
\hline Характеристика & $\begin{array}{l}\text { РЙРM } \\
(\mathrm{n}=65)\end{array}$ & $\begin{array}{l}\text { РЙЧМ } \\
(n=30)\end{array}$ & $\mathrm{p}$ \\
\hline Особливі фенотипи & $26(17)^{*}$ & 0 & $p=0,002$ \\
\hline $\begin{array}{l}\text { Структури псамомних } \\
\text { тілець і тиреоцитів }\end{array}$ & $24(16)^{*}$ & 0 & $\begin{array}{l}\mathrm{p}=0,0029 \\
\mathrm{p}=0,0073 \\
\text { (поправка Йєтса) }\end{array}$ \\
\hline Кістозна дегенерація & $37(24)^{*}$ & $1,5(1)$ & $\begin{array}{l}\mathrm{p}=0,0005 \\
\mathrm{p}=0,0014 \\
(\text { поправка Й } \in \mathrm{T} с \mathrm{)})\end{array}$ \\
\hline Оксифільні зміни & $10,77(7)$ & $3,08(2)$ & $\begin{array}{l}\mathrm{p}=0,527 \\
\mathrm{p}=0,7965 \\
\text { (поправка Йєтса) }\end{array}$ \\
\hline $\begin{array}{l}\text { ТПО-позитивні клітини } \\
(\mathrm{Mе}, \%)\end{array}$ & $0^{\#}$ & 77,5 & $p=0$ \\
\hline $\begin{array}{l}\text { ТГ-позитивні клітини } \\
\text { (Ме, \%) }\end{array}$ & $56^{\#}$ & 92 & $p=0,000002$ \\
\hline
\end{tabular}

Примітка: *- вірогідна різниця $(p<0,05)$ за методом $\chi^{2}$;

\#- вірогідна різниця $(p<0,05)$ за методом Манна - Уітні.

ності. УЗ-ознаку кістозної дегенерації виявляли в 1,8 раза частіше в РЙРМ, ніж у РЙЧМ (43,07\% і 23,3\% відповідно). Цитологічно цю ознаку виявляли приблизно в такому ж відсотку пунктатів РЙРМ (37\%), але майже не виявляли в пункційному матеріалі РЙЧМ. Можливо, це пов'язано 3 типом кістозних змін метастазу. Так, у метастазах із губчастим типом кістозних змін імовірність виявлення цієї ознаки за даними ТАПБ є більшою, ніж у метастазах із масивним кістозним компонентом. Цитологічні дослідження демонструють наявність певних цитологічних та імуноцитохімічних ознак, які дозволяють передбачити радіойодрезистентність поопераційних метастазів ПК ЩЗ. Проведення ТАПБ підозрілих за даними УЗД лімфатичних вузлів із подальшим цитологічним та імуноцитохімічним дослідженням дозволяє прогнозувати здатність метастазів до накопичення радіойоду.

\section{Висновки}

1. Ультразвукове дослідження є швидким та інформативним методом виявлення метастатичних уражень лімфатичних вузлів шиї.

2. За даними ультразвукових досліджень не виявлено достовірних змін, які дозволили б проводити диференційну діагностику між радіойодрезистентними та радіойодчутливими метастазами папілярної карциноми щитоподібної залози. Водночас кістозна дегенерація ви- 
Оригінальні дослідження

являється методом ультразвукової діагностики в 1,8 раза частіше в радіойодрезистентних метастазах, ніж у радіойодчутливих. Гіпоехогенні метастази в латеральних лімфатичних колекторах у переважній більшості випадків становлять радіойодрезистентні метастази.

3. Визначено цитологічні ознаки радіойодрезистентних метастазів папілярної карциноми щитоподібної залози, які дозволяють прогнозувати їх перед операцією.

4. Продемонстровано вірогідну редукцію експресії тиреоїдної пероксидази та тиреоглобуліну в пунктатах радіойодрезистентних метастазів порівняно з радіойодчутливими, що є підставою передопераційного прогнозування радіойодрезистентності поопераційних метастазів папілярної карциноми щитоподібної залози.

5. Виявлені за даними ультразвукового дослідження метастатичні лімфатичні вузли шиї дозволяють проводити подальші імуноцитохімічні та цитологічні дослідження, що може підвищити ефективність діагностики метастазів високодиференційованого раку щитоподібної залози й розробити тактику подальшого лікування.

\section{Список використаної літератури}

1. Tronko M, Bogdanova T, Shpak V. Thyroid cancer in Ukraine during 1986-2014. Health effects of Chornobyl accident. Thirty years aftermath. Kyiv: DIA. 20166Ж: 85-103.

2. Bogdanova T, Saenko V, Shpak V. Long-term analysis of the incidence and histopathology of thyroid cancer in Ukraine in adult patients who were children and adolescents at the time of the Chernobyl accident. In: Yamashita S, Thomas G, eds. Thyroid cancer and nuclear accidents - long term after effects of Chernobyl and Fukushima. Amsterdam: Elsevier. 2017:67-76.

3. Bogdanova T, Zurnadzhy L, Nikiforov Y. Histopathological features of papillary thyroid carcinomas detected during four screening examinations of a Ukrainian-American cohort. $\mathrm{Br} \mathrm{J}$ Cancer. 2015;113:1556-64.

4. Drozd V, Branovan I, Shiglik N. Thyroid cancer induction: nitrates as independent risk factors or risk modulators after radiation exposure, with a focus on the Chernobyl accident. Eur Thyroid J. 2018;7:67-74.

5. Dzepina D, Zurak K, Petric V, Cupic H. Pathological characteristics and clinical perspectives of papillary thyroid cancer: study of 714 patients. Eur Arch Otorhinolarygol. 2014;271(1):141-8.

6. Lei S, Ding Z, Ge J, Zhao D. Association between prognostic factors and clinical outcome of well-differentiated thyroid carcinoma: a retrospective 10-year follow-up study. Oncol Lett. 2015;10(3):1749-54

7. Markovina S, Grigsby PW, Schwarz JK. Treatment approach, surveillance, and outcome of well-differentiated thyroid cancer in childhood and adolescence. Thyroid. 2014;24(7):1121-6.

8. Machens A, Dralle H. Disease-free survival and time bias in long-term follow-up after complete resection of localized well-differentiated cancer. Ann Surg Oncol. 2011;18(2):600-18.

9. Patel SS, Goldfarb M. Well-differentiated thyroid carcinoma: the role of post-operative radioactive iodine administration. J Surg Oncol. 2013;107(6):665-72.

10. Haugen B, Alexander E, Bible K. American Thyroid Association management guidelines for adult patients with thyroid nodule sand differentiated thyroid cancer: The American Thyroid Association guidelines task force on thyroid nodules and differentiated thyroid cancer. Thyroid 2016;26:1-133

11. Worden F. Treatment strategies for radioactive iodine-refractory differentiated thyroid cancer. Ther Adv Med Oncol 2014; 6: 267-79.

12. Vaisman F, Carvalho D, Vaisman M. A new appraisal of iodine refractory thyroid cancer. Endocr Relat Cancer 2015; 22: R301-10.

13. Ahuja AT, Ying M, Ho SY. Ultrasound of malignant cervical lymph nodes. Cancer Imaging. 2008;86:48-56.

14. Yuchen Jina, Douglas Van Nostrand, Lingxiao Chenga, Min Liua, Libo Chena. Radioiodine refractory differentiated thyroid cancer. Oncolog/Hematology. 2018;125:111-20

15. Choi JW, Lee JH, Baek, JH. Diagnostic accuracy of ultrasound and 18-F-FDG PET or PET/CT for patients with suspected recurrent papillary thyroid carcinoma. Ultrasound Med Biol. 2010; 36:1608-15.

16. Ying M., Ahuja A. Sonography of neck lymph nodes. Part I: Normal lymph nodes. Clinical Radiology. 2003;58:351-8.

17. Nguyen QT, Lee EJ, Huang MG. Diagnosis and treatment of patients with thyroid cancer. Am Health Drug Benefits. 2015;8(1): 30-40.

18. Tomoda C, Sugino K, Matsuzu K. Cervical lymph node metastases after thyroidectomy for papillary thyroid carcinoma usually remain stable for years. Thyroid. 2016;26:1706-11.

19. Rivera M, Ghossein R, Schoder H. Histopathologic characterization of radioactive iodine-refractory fluorodeoxyglucose-positron emission tomography-positive thyroid carcinoma. Cancer 2008;113:48-56.

20. Deandreis D, Ghuzlan A, Leboulleux S. Do histological, immunohistochemical, and metabolic (radioiodine and fluorodeoxyglucose uptakes) patterns of metastatic thyroid cancer correlate with patient outcome? Endocr Relat Cancer. 2011;1:159-69.

21. Mian C, Barollo S, Pennelit G. Molecular characteristics in papillary thyroid cancers (PTCs) with no 131 I uptake. Clin Endocrinol. 2008; 68(1):108-16.

22. Bozhok Y, Tavokina L, Epstein E. The new things in diagnostic of thyroid cancer. Optimal combination of morphological and immunocytochemistry research methods of punctious materials. Med An. 1996;138:40-3.

23. Lastra R, Livolsi V, Baloch Z. Aggressive variants of follicular cellderived thyroid carcinomas: a cytopathologist's perspective. Cancer cytopathology. 2014;122:484-503.

24. Yunjun Wang, Qing Guan, Jun Xiang. Clinicopathologic features and prognostic factors of diffuse sclerosing variant of papillary thyroid carcinoma: a population based analysis. Translational cancer research. 2018; 7(3):40-5.

25. DeLellis RA, LloydR, Heitz PU (eds). Tumours of the thyroid and parathyroid. Tumours of Endocrine Organs, Pathology \& Genetics, World Health Organization Classification of Tumours. IARC Press, Lyon 2004:49-134.

26. Тронько НД, Комиссаренко ИВ, Коваленко АЕ, Кваченюк АН, Болгов МЮ. Состояние и перспективы развития эндокринной хирургии в Украине. Здоровье Украины. 2009;10:48-49. (Tronko ND, Komissarenko IV, Kovalenko AE, Kvachenyuk AN, Bolgov MYu. The state and prospects of the development of endocrine surgery in Ukraine. Health of Ukraine. 2009;10:48-49.)

(Надійшла до редакиії 11.11.2019 р.)

\section{Ультразвуковые и цитологические характеристики радиойодчувствительности метастазов папиллярного рака щитовидной железы}

\section{А.В. Зелинская, Е.А. Шелковой}

ГУ «Институт эндокринологии и обмена веществ им. В.П. Комиссаренко НАМН Украины»

Резюме. Цель - исследование ультразвуковых и цитологических характеристик метастазов, выявленных в постоперационный период, в зависимости от их йоднакопительной способности. 
Материал и методы. Ультразвуковые, цитологические, иммуноцитохимические исследования проводили на группе метастазов папиллярного рака щитовидной железы, выявленных в постоперационный период (после тиреоидэктомии и радиойодтерапии): 30 радиойодчувствительных метастазов и 65 радиойодрезистентных. Оценивали такие ультразвуковые характеристики, как локализация метастазов, являются ли они множественными или единичными, эхогенность, эхоструктуру и наличие гиперэхогенных включений. Цитологические и иммуноцитохимические исследования проводили на пункционном материале данных метастазов, окрашенном по Романовскому. Использовали косвенный иммунопероксидазный метод с моноклональными антителами к тиреоидной пероксидазе и тиреоглобулину. Статистический анализ проводили по напараметрическому критерию Манна - Уитни и методом $\chi^{2}$ в программе Statistica 11.0. Результаты. Проведенные исследования ультразвуковых и цитологических характеристик постоперационных метастазов папиллярных карцином щитовидной железы не обнаружили значимых различий между группами радиойодрезистентных и радиойодчувствительных метастазов по таким ультразвуковыми характеристиками, как ехогенность, эхоструктура и наличие гиперэхогенных включений. Показано, что в случаях выявления гипоэхогенных метастазов в латеральных лимфатических коллекторах вероятность радиойодрезистентности метастазов составляет 93 $2 \%$. Ультразвуковые признаки кистозной дегенерации выявляли в 1,8 раза чаще в радиойодрезистентных метастазах по сравнению с радиойодчувствительными. Цитологические исследования показали фенотипическую гетерогенность эпителия радиойодрезистентных метастазов по сравнению с радиойодчувствительными и достоверную разницу в экспрессии тиреоглобулина и тиреоидной пероксидазы. Выводы. По данным ультразвукового исследования не выявлено достоверных изменений, которые позволили бы проводить дифференциальную диагностику между радиойодрезистентными и радиойодчувствительными метастазами папиллярного рака щитовидной железы. Определены цитологические признаки радиойодрезистентных метастазов папиллярного тиреоидного рака, которые делают возможным их предоперационное прогнозирование. Продемонстрирована значимая редукция экспрессии тиреоидной пероксидазы и тиреоглобулина в пунктатах радиойодрезистентных метастазов по сравнению с радиойодчувствительными, что является основанием для предоперационного прогнозирования радиойодрезистентности постоперационных метастазов папиллярного тиреоидного рака. Выявленные по данным ультразвуковой диагностики метастатические лимфатические узлы шеи позволяют проводить дальнейшие иммуноцитохимические и цитологические исследования, что может повысить эффективность диагностики метастазов высокодифференцированного рака щитовидной железы и облегчить выбор дальнейшего лечения.

Ключевые слова: папиллярная карцинома щитовидной железы, ультразвуковое исследование, тонкоигольная аспирационная пункционная биопсия, радойодрезистентные метастазы.

\section{Ultrasound and cytological characteristics of radiosensitivity of papillary thyroid cancer metastases}

\section{G.V.Zelinskaya, E.A. Shelkovoy}

SI «V.P. Komisarenko Institute of Endocrinology and Metabolism of Academy of Medical Science of Ukraine»

Abstract. Aim is ultrasound and cytological studies of metastases detected in the postoperative period depending on their iodine accumulation capacity. Material and methods. Ultrasound, cytological, immunocytochemical studies on a group of papillary thyroid cancer metastases detected in the postoperative period (after thyroidectomy and radioiodine therapy) (30 - radioiodine-sensitive metastases, 65 - radioiodine-refractory metatases) were performed. Ultrasound characteristics such as localization of metastases, whether multiple or isolated, echogenicity, echostructure, and the presence of echo (+) inclusions were evaluated. Cytological and immunocytochemical studies on the FNA smears of these metastatic groups, stained according to Romanovsky were performed. Indirect immunoperoxidase method using monoclonal antibodies to thyroid peroxidase and thyroglobulin was used. Statistical analysis using the U-test and the $\chi^{2}$ method in Statistica.11 package was performed. Results. Investigations of ultrasound and cytological characteristics of postoperative metastases of papillary thyroid carcinomas did not reveal statistically significance difference between groups of radioiodine-resistant and radioiodinesensitive metastases on such ultrasound characteristics as echogenicity and echostructure and presence of echo $(+)$ inclusions It is shown that when hypoechogenicity metastases are detected in the lateral lymphatic collectors, the probability of radioiodine resistance of metastases is $93 \pm 2$. The ultrasound sign of cystic degeneration was found 1.8 times more frequent in radioiodine-resistance metastases compared to radioiodine-sensitive metastases. Cytological studies demonstrate the phenotypic heterogeneity of epithelium of radiiodine-resistant metastases compared to radioiodine-sensitive metastases and statistically significance difference in the expression of thyroglobulin and thyroid peroxidase were detected. Conclusions. Ultrasound revealed no statistically significant changes that would allow differential diagnosis between radioiodine-resistant and radioiodine-sensitive metastases of papillary thyroid cancer. Cytologic features of radioiodine-resistant metastases of papillary thyroid cancer have been demonstrated, which allow their preoperative prognosis. A statistically significant reduction in the expression of thyroid peroxidase and thyroglobulin in FNA smears of radioiodine-resistant metastases compared with radioiodine-sensitive metastases, which is the basis of preoperative prognosis of radioiodine-resistance of postoperative metastases has been demonstrated. The metastatic neck lymph nodes, identified by ultrasound diagnostics, allow for further immunocytochemical and cytological studies, which can improve the diagnosis of metastases of highly differentiated thyroid cancer and provide a choice of further treatment.

Keywords: papillary thyroid carcinoma, ultrasound, fine-needle aspiration biopsy, FNA smears, radioiodine-resistant metastases. 